\title{
MEDIA PORTRAYALS OF REGIONS IN THE CZECH REPUBLIC: SELECTED ISSUES
}

\author{
Jan Sucháček, Petr Sed’a, Václav Friedrich, Jaroslav Koutský
}

\section{Introduction}

Not surprisingly, $21^{\text {st }}$ century is quite frequently referred to as the century of information. Informational needs currently represent such an important category that they are comparable with the saturation of physiological needs. Less attention is usually devoted to the territorial patterns of information.

Every territory can be characterized by both material and intangible characteristics [1], [20]. Spatial distribution of population is of utmost importance in this respect as human activities form material structures, which surround us. Nonetheless, all territories are describable also from intangible perspective. Overall atmosphere, reputation, image as well as position on the mental map can be ranked among typical attributes of the intangible dimension of the space [9], [16], [19].

Mental maps represent increasingly popular notion of our times. Mental maps are formed on the basis of aggregation of individual images of particular spots and territories. From this standpoint, the image of the territory should be perceived as overall picture and reputation of given area in the eyes of the wide public. Mental maps reflect the psychological representation of space. [5] showed that mental maps are not mere preference surfaces but also predictors of consequent spatial behavior. Growing importance of mental maps is in compliance with recent upsurge of soft location factors.

Media - and no matter whether printed, such as newspapers or journals, or electronic, such as TV, radio or on-line content - are undoubtedly the primary source of information. At the same time, media formed the environment that directs our everyday activities. Media influence the functioning of individual subjects as well as whole territories. In brief, individuals or enterprises that do not appear in media are losing their existence in virtual world and become inconspicuous in the real world as well. And the same applies to regions. Regions without media publicity are largely omitted by investors, tourists as well as wide public. If the region appears in the media it still does not mean any victory since investors, tourists and the wide public are pretty sensitive on the composition of news about individual territories. If the region is depicted in a positive way, it often lures the above mentioned target groups; vice versa, negative news repel these target groups and the region can easily fall into psychological and economic vicious circle. Put succinctly, media in relation to regional development do matter [4], [8], [10].

Media influence readers, listeners or TV viewers in the short run. In case that certain themes are repeated more frequently, attitudes and behavior of the population can be affected in the longer run. Further factors shaping mental maps in the longer run are educational institutions, family or surrounding milieu.

Image of the region should characterize its specific supply and distinctiveness. In reality, territorial image very often does not correspond to the objective reality, which is caused primarily by the processes of agenda-setting and agenda-cutting that are used in various kinds of media rather frequently.

The traditional mission of media is objective, accurate and unbiased depiction of reality. However, contemporary media can be already perceived as co-creators of the milieu we are living in. Regarding the great and steadily growing interconnectedness of the world, media can show just selective cuts of complex reality. People are thus informed about the events but at the same time media more or less conspicuously direct their behavior and the perception of 
reality. Many people even accept opinions presented by media in a very sophisticated way. Agenda-setting, i.e. accentuation of chosen events or agenda-cutting, i.e. ignorance of selected occurrences play increasingly important role in this context [11], [12].

At the same time, the possibilities to control whether media fulfill their mission, i.e. objective and unbiased coverage are practically eliminated, since there are not so many individuals that possess sufficient time and energy to check the primary sources of information and to verify the validity of media informing. Moreover, the quality of information itself is heavily dependent upon the way of interpretation and explanation of events or phenomena. Indeed, media bias is one of the most important attributes of contemporary coverage.

From this point of view, the conception of gatekeeping is of great importance. Gatekeeping should be treated as the process through which information is filtered for dissemination, be it publication, broadcasting, internet or some other mode of communication. Gatekeeping ranges from a reporter deciding which sources are selected to be included in a story to editors determining which stories are printed or covered. The process concerns also media owners as well as advertisers.

Process of gatekeeping designs not only which information is chosen, but also what the content and nature of the messages, such as news, will be. The most important attributes of gatekeeping are as follows [2], [15]:

- In accomplishing their monitoring functions, all media have a very large amount of stories brought every day by reporters.

- Only a limited amount of time or space is available in any medium for its daily presentations of the news to its audience. The remaining room is devoted primarily to advertising.

- Within any news organization there exists a news perspective, a subculture sui generis that includes a complex set of criteria for evaluating a particular news story - criteria based on economic needs of the medium, organizational policies and some other categories.

- The above criteria are used by editors, news directors, and other personnel who select a limited number of news stories for presentation to the public. These news are presented in ways such that the requirements of the medium and the preferences of the audience are met.

- Personnel in the media is acting as gatekeepers, letting some stories pass through the system but keeping others out, thus limiting, controlling, and shaping the public's knowledge of the entirety of actual events taking place in reality.

From territorial point of view, media constitute certain informational gate between inner, i.e. municipal and regional actors of territorial development and outer groups, such as visitors, potential visitors, investors, non-regional entrepreneurs etc. Local/regional politicians, institutions or entrepreneurial subjects strive for the attraction of media attention and address their voters, citizens or employees just by means of media. And vice versa, these relevant players of local and regional development get the important information for their decisionmaking through media again. Not surprisingly, media by themselves became relevant actors of territorial development. Subsequently, we are currently entitled to speak about media-territorial or directly meditorial development, rather than about mere territorial development [17].

We can distinguish local, regional and national media. Basically, it is scalar differentiation of media. Obviously, national media are the most influential ones. For the purposes of our work, we will focus primarily upon national media, because they inform not only about national or foreign issues but also about particular regions. And just the news concerning regions that are mentioned at the national level substantially codetermine the creation of mental maps.

In many countries, spatial distribution of media is rather centralized and all principal media are concentrated usually into the capital city, which is also the case of Czech Republic. At the same time, one has to consider that above media centres typically act also as administrative, political and socio-cultural hubs. This is the factor that may affect territorial pattern and composition of the news. However, there are much more sources of media bias.

In order to capture the relation between media and regions, authors of this paper focused on TV. TV coverage has one of the highest impacts on the public on the one hand and is representative enough on the other [14]. Comparisons show that TV coverage agenda to a large 
extent represents also press or radio coverage agenda [14]. That is why TV coverage will be taken as a point of departure for this research.

The main objective of this article is to analyze and evaluate selected aspects of NUTS III regions portrayals within national TV coverage. Whole research has been accomplished primarily from qualitative point of view. Added value of the paper is substantially influenced by the relative newness of the whole topic.

\section{Materials and Methods}

The empirical analysis in this paper is based on unique data purchased from Media Tenor, Ltd. This company deals with a continuous and systematic analysis of media reports in the Czech Republic. The Media Tenor, Ltd. offers a complete set of analytical services based on the content analysis of media. It accurately evaluates both qualitative and quantitative aspects of media contributions. Analytical and consulting services are usually used by private companies, political parties, PR agencies, local governments, scholars as well as media editors.

In this paper, we investigated TV coverage which was represented by evening news of 3 principal TV companies in the Czech Republic. Our research therefore monitored Události and Události, komentáře of Czech TV, both of them representing public TV. On the other hand, Zprávy constitutes part of private FTV Prima air time and the same applies to Televizní noviny of TV Nova. Our research covers the period between 2004 and 2011 years, which is maximum possible time in this realm. Thus one can already get at least an essential overview of developmental tendencies in the researched domain.

Our analysis and interpretation is based on content structure of contributions appearing in national TVs and related to individual NUTS III regions in the Czech Republic. Individual themes related to country's self-governing regions include relevant economic, social as well as environmental aspects of life in these territories.

For the purposes of this text, three basic research hypotheses have been formulated. The hypotheses tested in our paper are defined as follows:

$H 1$ : The average number of contributions in each thematic pillar is comparable within individual regions.

H2: The representation of contributions from a particular pillar is comparable among regions.
H3: Independence between region and pillar variables can be expected.

In this paper, the methods of correspondence analysis and Kruskal-Wallis test procedure will be utilised. The Kruskal-Wallis test or nonparametric analysis of variance (ANOVA) is usually used when one wants to test the difference between two or more groups when data sample doesn't meet assumption of normality. Correspondence analysis is appropriate approach when attempting to determine the proximal relationships among two or more categorical variables. When having categorical variables the method of correspondence analysis is similar to the usage of correlation analysis or principal components analysis for continuous or nearly continuous variables.

\subsection{Analysis of Variance}

The first analytical approach, which will be applied in this paper, is the analysis of variance, namely the Kruskal-Wallis test. The Kruskal-Wallis test is usually used when there is one nominal variable and one measurement variable, and the measurement variable does not meet an assumption of normality. In that case, a standard one-way ANOVA may lead to inaccurate estimates of the $p$-value when the data are very far from normal distribution. The Kruskal-Wallis test belongs to a group of nonparametric tests and is equivalent to the standard one-way ANOVA. This test is a logical extension of the Mann-Whitney $U$ test and allows us the comparison of more than two independent groups. It is most commonly used when we wish to compare three or more sets of scores that come from different groups [13].

The Kruskal-Wallis test does not expect an assumption that the data are normally distributed. However, it does assume that the observations in each group come from populations with the same shape of distribution. In other words, if different groups have different shapes, for instance one is skewed to the left and another one is skewed to the right, or they have different variances, the Kruskal-Wallis test may give inaccurate results. For details, see [3]. In that kind of situation, maybe one could look into some kind of bootstrap analysis.

The null hypothesis in case of the KruskalWallis test is that the samples come from populations with certain characteristics. These characteristics entail there is 0.5 probability that 
a random observation from one group is greater than a random observation from another group. The Kruskal-Wallis test does not test the null hypothesis that the populations have identical means, which is the null hypothesis in case of one-way ANOVA. The Kruskal-Wallis test also does not test the null hypothesis that the populations have equal medians, although you will see this error in some statistics textbooks.

Like most non-parametric tests, the Kruskal-Wallis test is also performed on ranked data, so that observations are converted to their ranks in the overall data set, and the smallest value gets a rank of 1 , the next smallest gets a rank of 2 , etc. Tied observations get average ranks; therefore if there were two identical values occupying the seventh and eighth smallest places, all would get a rank of 7.5 etc.

The sum of the ranks is calculated for each group, then the test statistic $\mathrm{H}$ is calculated. $\mathrm{H}$ is given by a rather formidable formula that basically represents the variance of the ranks among groups, with an adjustment for the number of ties. If the null hypothesis is true, the test statistic $\mathrm{H}$ is approximately chi-square distributed, which means that the probability of getting a particular value of $\mathrm{H}$ by chance is the $\mathrm{p}$-value corresponding to a chi-square equal to $\mathrm{H}$. The degrees of freedom represent the number of groups minus 1 .

Analysis of variance will be utilised for the verification of hypotheses $\mathrm{H} 1$ and $\mathrm{H} 2$.

\subsection{Measurement of Correspondence in a Crosstabulation}

Correspondence analysis is a multivariate statistical technique proposed by [7] and later developed by [6]. The correspondence analysis denotes a nonparametric approach which does not calculate any statistical significance test since it is not based on a probability distribution assumption.

The correspondence analysis itself represents an algorithm which is capable of some measurement of correspondence between the rows and the columns in a correspondence table. When centring the columns and rows of correspondence table and using chi-square distances it corresponds to standard correspondence analysis. Nevertheless, using alternative centring ways combined with another type of distances allows for an alternative representation of correspondence table in a low-dimensional space.
As the measure of correspondence any association, similarity, confusion or interaction between the column and row variables can be considered. Common type of correspondence table is a crosstabulation with the cells containing frequency counts. However, when using a typical crosstabulation it does not usually provide a clear picture of the nature of correspondence between variables, especially if the variables of interest are nominal and in addition contain numerous categories.

To summarize, correspondence analysis is usually performed on contingency tables of size $m \times n$ where $m$ represents the number of rows and $n$ denotes the number of columns in a contingency table. From statistical point of view, a crosstabulation is a type of table in a matrix format that displays the multivariate frequency distribution of the variables. A crucial problem of multivariate statistics is finding dependence structure underlying the variables contained in high dimensional contingency tables.

When using correspondence analysis approach, a contingency table of frequencies is usually standardized firstly. Thus, the relative frequencies across all cells sum to 1.0. In typical correspondence analysis the entries in the table represent the relative frequencies in terms of the distances between individual columns and rows in a low-dimensional space. When applying correspondence analysis procedure, all used data should be nonnegative and moreover on the same scale. The method of correspondence analysis deals with rows and columns equivalently.

The contingency tables offer several measures of association and tests of association. For instance, chi-square test, Fisher's exact test, Phi coefficient, contingence coefficient $\mathrm{C}$ or Cramer's $\mathrm{V}$ can be used. An analysis of contingency tables usually includes investigation of row and column profiles and testing for independence via the chi-square test.

The correspondence analysis decomposes the $\chi^{2}$ statistic associated with this table into orthogonal factors. A chi-squared test, also referred to $\chi^{2}$ test, is statistical hypothesis test in which the sampling distribution of the test statistic is a chi-squared distribution when the null hypothesis is true. Since correspondence analysis is only descriptive technique, it can be applied to tables whether the $\chi^{2}$ statistic is appropriate or not. When the number of 
categories is quite large and the assumptions of chi-square test are not fulfilled, the chisquare test sometimes is not able to detect the dependence structure clearly.

The correspondence analysis is able to examine the relationship between two variables graphically in multidimensional space. One can compute column and row scores and make a plot based on the scores. Thus, the basic aim of correspondence analysis is to create biplots for correspondence tables. The correspondence plot allows us to visualize mutual relationships among categories spatially on dimensional axes. In other words, with a help of empirically derived dimensions it can be seen which categories are close to other categories. Therefore, projecting points for one variable on the vector from the origin to a category point of the other variable represents the relationship between analysed variables.

To sum it up, with a help of this approach one can see which categories of used variable are similar to each other or/and which categories of two different variables are related. Moreover, correspondence analysis procedure allows us to fit supplementary points into a space which has been defined by active points.

Correspondence analysis is able to work with nominal variables, ordinal variables, and also with ratio variables, albeit creation of discrete categories from a continuous variable is generally not recommended. Since in a typical correspondence table, variables in the rows and columns are assumed to denote unordered categories, the nominal scaling is usually used. It means that the only consideration is the fact that some objects are in the same category while others are not. Nothing can be assumed about the distance or order between categories of the same variable.

Correspondence analysis will be used for the evaluation of hypothesis $\mathrm{H} 3$.

\section{Results and Discussion}

Statistical analyzes presented in this paper were accomplished on the data file representing the individual contributions presented in the major news programs from different NUTS III regions in the public Czech Television (Události and Události, komentáře), commercial TV Nova (Televizní noviny) and FTV Prima (Zprávy) for the period from April 2004 to December 2011. Contributions are thematically divided into 30 categories and 10 pillars (social, environmental, economic, education and science, public affairs, European and international, security, accidents, sport and justice). Altogether the amount of 54,667 contributions was monitored by this way.

Statistical data were analysed by means of contingency tables, correspondence analysis and non-parametric Kruskal-Wallis test with a help of Microsoft Excel and IBM SPSS Statistics software.

\subsection{Description of Data Set}

As a first step of our analysis we divided default 30 thematic categories of original data sets ob-

Tab. 1: Distribution of particular thematic pillars

\begin{tabular}{l|c|c} 
& Frequency & Percent \\
\hline SECURITY & 13,630 & 24.9 \\
\hline SOCIAL & 12,826 & 23.5 \\
\hline ACCIDENTS & 10,213 & 18.7 \\
\hline ECONOMIC & 5,731 & 10.5 \\
\hline PUBLIC AFFAIRS & 4,030 & 7.4 \\
\hline ENVIRONMENTAL & 3,213 & 5.9 \\
\hline JUSTICE & 2,147 & 3.9 \\
\hline EUROPEAN \& INTERNATIONAL & 1,106 & 2.0 \\
\hline EDUCATION \& SCIENCE & 983 & 1.8 \\
\hline SPORT & 788 & 1.4 \\
\hline Total & 54,667 & 100.0 \\
\hline
\end{tabular}


tained by Media Tenor Ltd. into 10 basic thematic pillars in order to simplify their classification. The description of original data and default 30 categories can be found in [17] and [18]. Before the analyses the source data were transformed from Excel tables into uniform datasheet for IBM SPSS Statistics software and categorized by authors. Tab. 1 shows the distribution of all the news among particular pillars.

Almost one half of the news (49.5\%) is of tabloid character, which includes security, accidents and justice. This is in line with gatekeeping conception that has much to do with editorial stereotypes (see also [15]). As it can be seen in Table 1, security and accident pillars together with social pillar occupy the top of the rankings. European \& international and education \& science pillars have remained at the opposite end of the ladder together with sport pillar.

In order to describe mutual interdependence among thematic pillars and news programs contingency table was created, see Tab. 2. Table 2 provides us with synthetic information about percentage distribution of individual thematic pillars within researched news programs.

\section{Tab. 2: Contingency table (\% within news program)}

\begin{tabular}{l|c|c|c|c|c} 
& \multicolumn{4}{|c|}{ News Program } & \multirow{2}{*}{ Total } \\
\cline { 2 - 5 } & $\begin{array}{c}\text { Televizní } \\
\text { noviny } \\
\text { (Nova TV) }\end{array}$ & $\begin{array}{c}\text { Události } \\
\text { (CT) }\end{array}$ & $\begin{array}{c}\text { Události, } \\
\text { komentáře } \\
\text { (CT) }\end{array}$ & $\begin{array}{c}\text { Zprávy } \\
\text { (FTV Prima) }\end{array}$ & \\
\hline SECURITY & $30.6 \%$ & $19.3 \%$ & $17.2 \%$ & $26.8 \%$ & $24.9 \%$ \\
\hline SOCIAL & $21.1 \%$ & $28.3 \%$ & $26.7 \%$ & $20.2 \%$ & $23.5 \%$ \\
\hline ACCIDENTS & $20.0 \%$ & $14.8 \%$ & $15.0 \%$ & $22.4 \%$ & $18.7 \%$ \\
\hline ECONOMIC & $9.0 \%$ & $11.3 \%$ & $14.9 \%$ & $9.6 \%$ & $10.5 \%$ \\
\hline PUBLIC AFFAIRS & $5.2 \%$ & $10.3 \%$ & $10.0 \%$ & $6.1 \%$ & $7.4 \%$ \\
\hline ENVIRONMENTAL & $7.1 \%$ & $4.6 \%$ & $3.6 \%$ & $6.5 \%$ & $5.9 \%$ \\
\hline JUSTICE & $3.2 \%$ & $4.5 \%$ & $5.5 \%$ & $3.6 \%$ & $3.9 \%$ \\
\hline EUROPEAN \& I & $1.3 \%$ & $2.9 \%$ & $3.2 \%$ & $1.5 \%$ & $2.0 \%$ \\
\hline NTERNATIONAL & $1.2 \%$ & $2.1 \%$ & $2.6 \%$ & $1.9 \%$ & $1.8 \%$ \\
\hline EDUCATION \& & $1.3 \%$ & $1.8 \%$ & $1.2 \%$ & $1.4 \%$ & $1.4 \%$ \\
\hline SCIENCE & $100 \%$ & $100 \%$ & $100 \%$ & $100 \%$ & $100 \%$ \\
\hline SPORT & $(18,558)$ & $(14,997)$ & $(6,139)$ & $(14,973)$ & $(54,667)$ \\
\hline Total & & & & & $5041 \%$ \\
\hline
\end{tabular}

Source: authors

While the public Czech TV has the largest share of contributions from social pillar, followed by security and accidents pillars, both commercial televisions (Nova TV, FTV Prima) have security pillar on the top, followed by relatively comparable proportion of social and accidents pillars. The economic and public affairs pillars have a greater representation in news programs of Czech TV. All TV stations have the smallest share of European \& international, sport and education \& science pillars.
As a next step of our analysis we measured potential dependence in Tab. 2. Results are shown in Tab. 3.

Pearson Chi-square test of independence shows that significant dependency of pillar structure on TV program exists (Sig. $=0.000$ ). The value of Cramer $V$ coefficient of contingency means the weak dependency only.

The maximal number of contributions is concentrated at Televizní noviny of Nova TV; slightly less contributions is brought by Události 
Tab. 3: Measures of dependence in contingency table

\begin{tabular}{l|c|c} 
& Value & Asymptotic Significance \\
\hline Pearson Chi-Square & $2,219.098$ & 0.000 \\
\hline Cramer's V & 0.116 & \\
\hline N of valid cases & 54,667 & \\
\hline
\end{tabular}

Source: authors

(Czech TV) and Zprávy (FTV Prima). The news program Události, komentáre (Czech TV) contains significantly smaller number of contributions, but this program is oriented into important and serious topics with more detailed analyses.

In order to present described interdependence among thematic pillars and news programs from visual perspective, the correspondence analysis containing 2 dimensions was used in the form of scatter plot, see Fig. 1.

The horizontal axis in Fig. 1 (Dimension 1) divides particular pillars into 3 basic segments: a) European \& international, public affairs (public topics),

b) Social, sport, justice, economic, education \& science (societal topics),

c) Security, environmental, accidents (tabloid topics).

On the other hand, the vertical axis in Fig. 1 (Dimension 2) subdivides all pillars into 2 segments:

a) Education \& science, economics, justice, accidents (everyday topics),

b) European \& international, public affairs, social, sport, environmental, security (remaining topics).

\section{Fig. 1: Scatter plot for pillars}

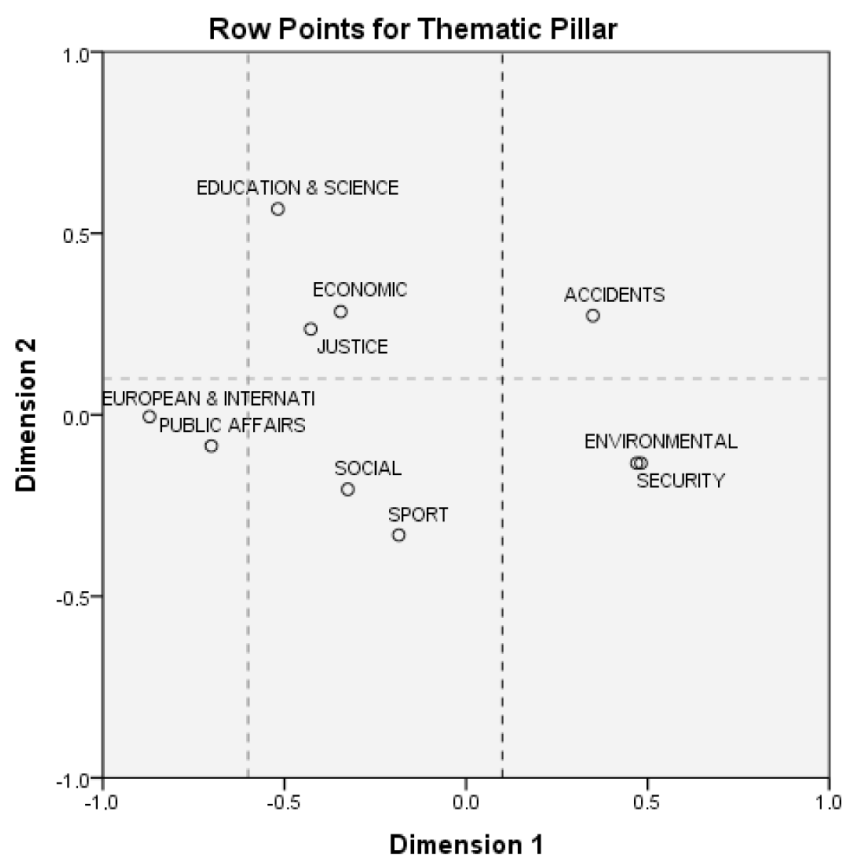

Source: authors 


\section{Marketing a obchod}

In order to clarify the profiles of above mentioned TV programs in a better way, we can display both pillars and TV programs through the correspondence analysis into one location map, see Fig. 2. Two dimensions of the correspondence analysis are covering approximately $98 \%$ of the variability of the original crosstable, which detects a very high rate of correspondence.

\section{Fig. 2: Scatter plot for both pillars and programs}

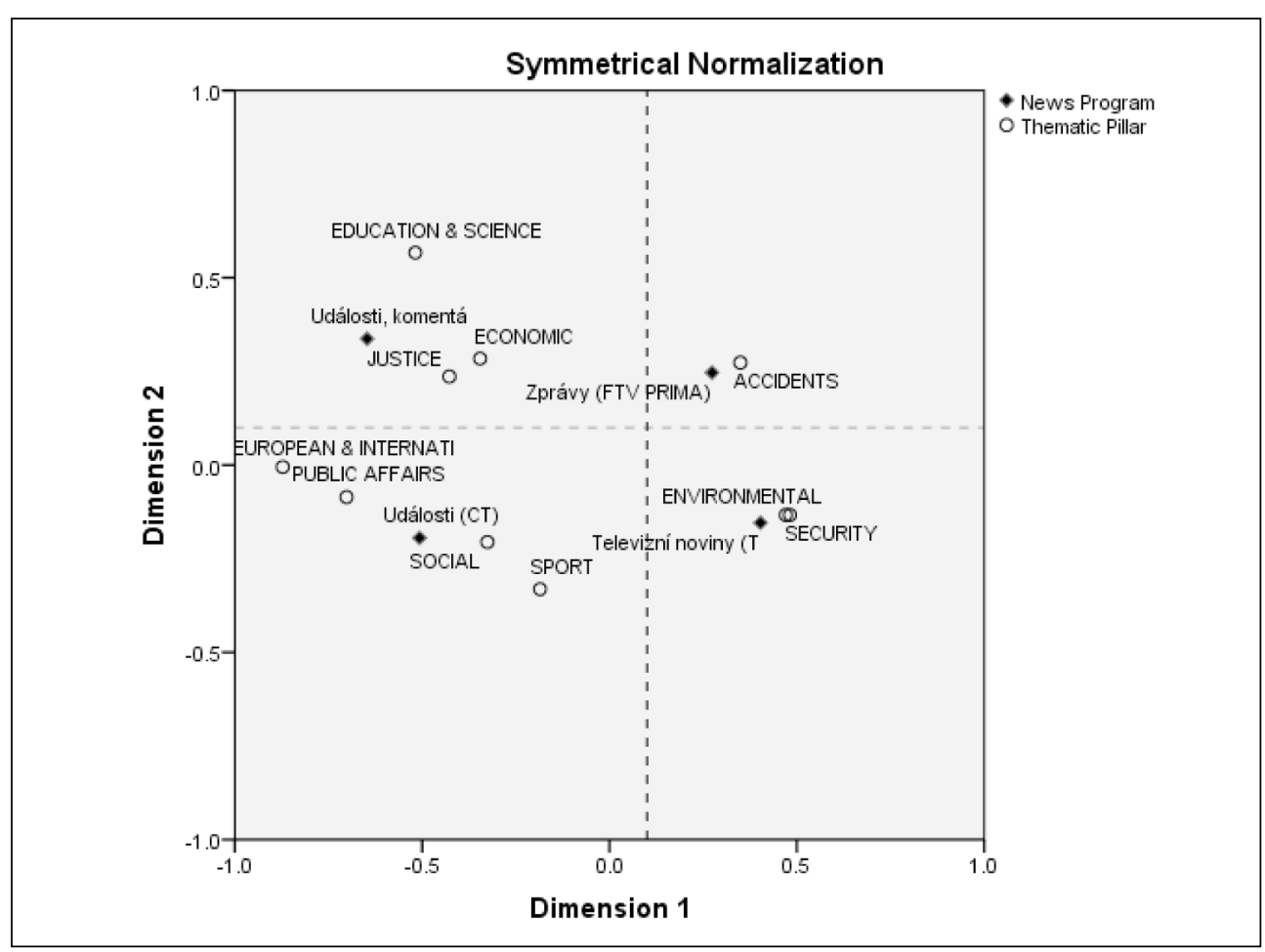

Source: authors

With the help of Fig. 2 one can determine which thematic pillars are more accentuated than the others in particular news programs. The first dimension (Dimension 1) divides the public news programs (on the left side of the plot) from the commercial ones (on the right). The second dimension (Dimension 2) facilitates the differentiation of TV news as to thematic categories. The content differences between the programs of public Czech TV are larger than the differences between the news programs of both commercial TV stations. It can be said that Události, komentáre (Czech TV) and Zprávy (FTV Prima) are orientated into more specific and profound topics.
The dimensions in Fig. 2 can be described as follows:

a) Dimension 1: public - commercial (tabloid),

b) Dimension 2: general (societal) - specific (familiar/individual).

From this perspective it is clear that Události of Czech TV program concentrates primarily on social, public affairs, European \& international, sport pillars, while Události, komentáre are focusing on economics, justice, education \& science pillars, which is distinctive in comparison with other TV programs. It is possible to claim that Czech TV is able to produce two different news programs with various specializations and more distinct profile. On the 
other hand Televizni Noviny of TV Nova is more focused on environmental and security pillars while other Zprávy of FTV Prima is closely linked to accidents pillar. The last result is consistent with the fact that FTV Prima produces a special part of news called Crime Report (Krimi Zprávy).

Results we obtained are in consonance with previous analyses [18].

\subsection{Appearance of News in Various Regions and Pillars}

In the next step of our empirical analysis all the hypotheses as formulated in chapter 2 will be verified. For the purposes of our analysis the default data were transformed into the structure with the following factors:

- region (covering NUTS III territories),

- year,

- thematic pillar.

The number of news per year, per NUTS III region and per particular pillar serves as quantitative indicators. It should be also mentioned that two NUTS III regions - Prague and Central Bohemia were joined into one territory. It was done due to the better correspondence with natural geographical characteristics on the one hand and suppression of specific urban character of the capital city on the other. Last but not least, unification of Prague and Central Bohemia into one territorial unit turned out to be correct and useful also in previous researches [17].

a) Hypothesis $H 1$ : The average number of contributions in each thematic pillar is comparable within individual regions.

We will compare the average annual number of posts in each region and pillars using onedimensional analysis of variance. Since the distribution of data set doesn't exhibit normal probability distribution as confirmed by JarqueBera test the non-parametric analysis of variance represented by Kruskal-Wallis test will be used.

First, it will be compared the average number of contributions per capita (per 100,000 inhabitants) for a region among particular pillars. Results of Kruskal-Wallis test are shown in Tab. 4.

\section{Tab. 4: Non-parametric analysis of variance (Kruskal-Wallis test)}

\begin{tabular}{c|c}
\multicolumn{2}{c}{ Number of news per capita } \\
\hline Kruskal-Wallis $H$ & 741.189 \\
\hline$d f$ & 9 \\
\hline Asymptotic Significance & 0.000 \\
\hline
\end{tabular}

Source: authors

The asymptotic significance is less than 0.05 , so the hypothesis $H 1$ can be rejected at $5 \%$ significance level which means that the differences in the number of contributions per capita among the pillars are statistically significant.

The largest amounts of contributions per capita throughout the Czech Republic are related to security, accident and social pillars. Our results confirm the previous research findings that in the news programs (especially in commercial TVs) tabloid topics are clearly [18]. The same result can be expressed via sorted means plot which is often used to describe the result of analysis of variance tests, see Fig. 3.

On the other hand, European \& international, education \& science and sport pillars proved to have the smallest share among all pillars. Moreover, the same applies to practically all NUTS III regions. The only exceptions are Karlovy Vary and unified Prague and Central Bohemia regions where social pillar is the most abundant one.

b) Hypothesis H2: The representation of contributions from a particular pillar is comparable among regions.

To evaluate hypothesis $H 2$ we will again utilise the analysis of variance with one factor. When accomplishing the analysis of variance, the average number of contributions for a pillar per capita (per 100,000 inhabitants) will be compared among individual NUTS III regions as the factor. 


\section{Fig. 3: Means plot for pillars}

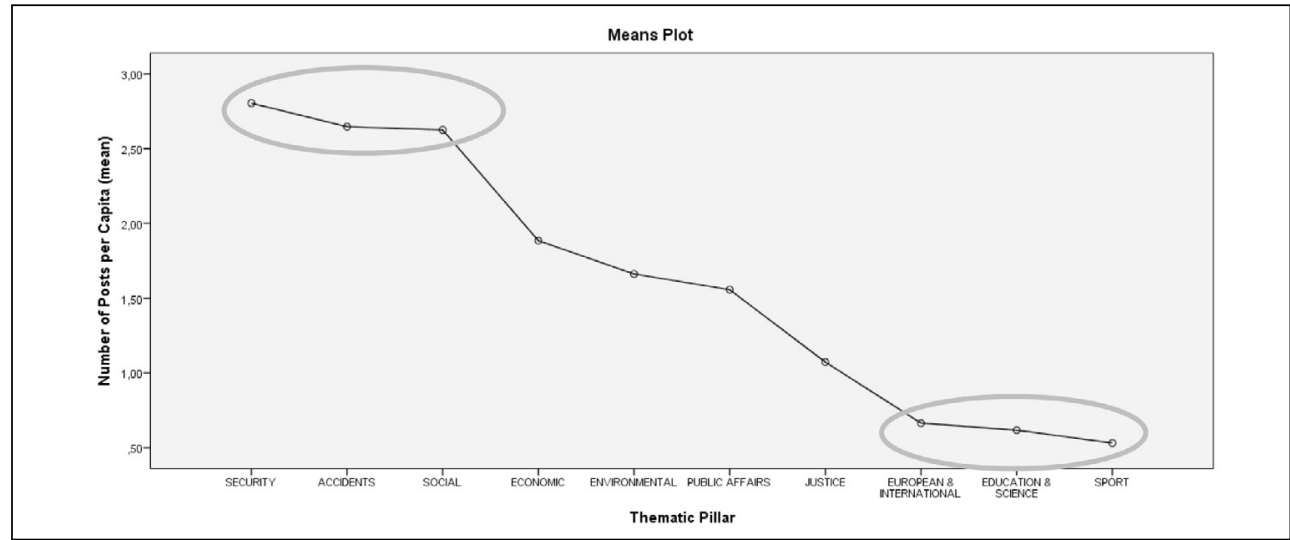

Source: authors

To test the differences between the regions the Kruskal-Wallis test will be used again because the probability distribution of data set doesn't exhibit normality. Results of the Kruskal-Wallis test for the hypothesis $H 2$ are shown in Tab. 5.

\section{Tab. 5: Non-parametric analysis of variance (Kruskal-Wallis test)}

\begin{tabular}{c|c}
\multicolumn{2}{c}{ Number of news per capita } \\
\hline Kruskal-Wallis $H$ & 33.110 \\
\hline$d f$ & 12 \\
\hline Asymptotic Significance & 0.001 \\
\hline
\end{tabular}

Source: authors

The hypothesis $\mathrm{H} 2$ of a comparable number of contributions among regions can be rejected, since asymptotic significance is less than 0.05 again. We must therefore assume that some regions are associated with more contributions than it would correspond to their population size. Similar results have been reached by application of regression analysis [18]. It has been confirmed that the number of contributions per capita decreases with the distance from the capital city.

If we display the sorted means plot, it is clear that equality is disrupted especially by Central Bohemia Region including Prague, which concentrates most of the contributions, even though we recalculated the number of contributions per capita. Moravian regions with the exception of South Moravia with Brno as the "capital" of Moravia are at the end of this sorted list; see Fig. 4.

When comparing the profiles of news per capita among regions for each pillar, we can find (compared to the previous hypothesis $\mathrm{H} 1$ ) significant differences between the pillars. It means that the order of regions in the profile is different just due to the pillar. For example, we can analyse education \& science pillar in more detail. The education \& science pillar has a clear peak in Plzeň region, followed by Liberec and Central Moravia \& Central Bohemia \& Prague regions, which can be related to the affair of Faculty of Law, University of West Bohemia in Plzen that was one of the most interesting news at a certain time. On other hand, Karlovy Vary region belongs to the regions with lowest number of contributions per 


\section{Fig. 4: Means plot for regions (NUTS III)}

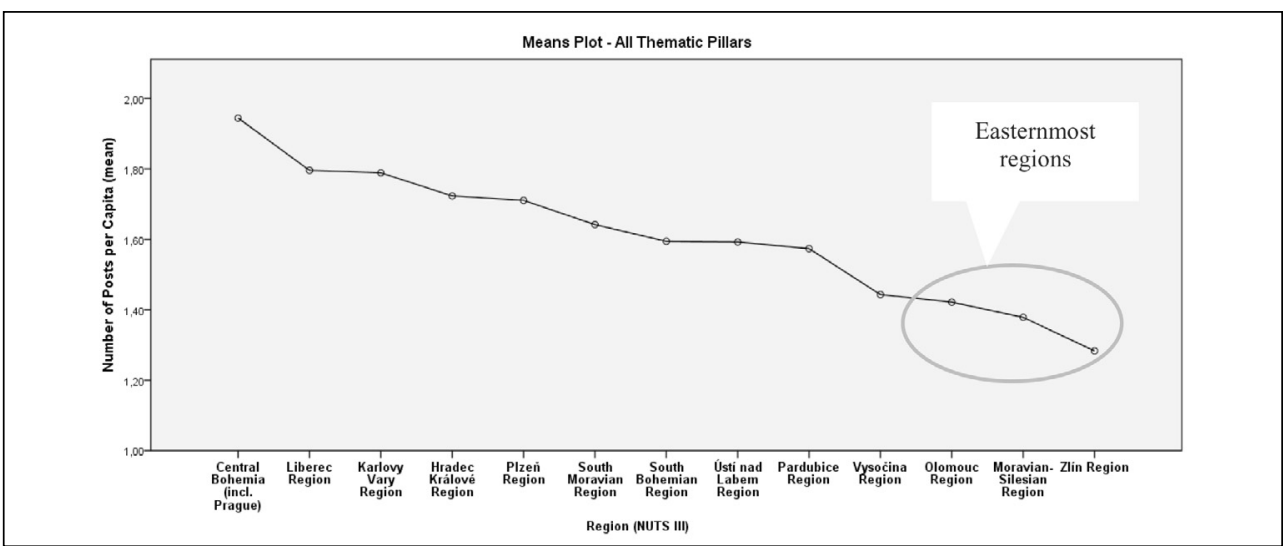

Source: authors

\section{Fig. 5: Means plot for education \& science pillar by regions (NUTS III)}

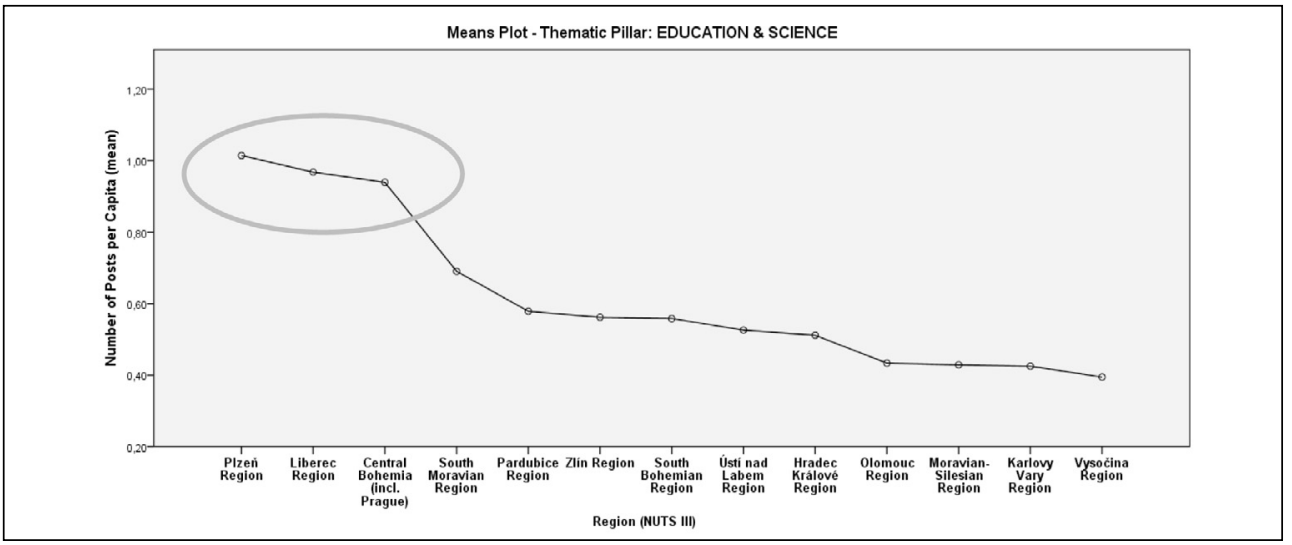

Source: authors

capita, which can be ascribed to the fact that Karlovy Vary is one of the few regional capitals without university or college, see Fig. 5.

It is worth noticing regions, which dominate in individual pillars. For instance, Central Bohemia \& Prague region always dominate in all investigated pillars. In other words, the "capital city" region is always among the top three regions when analysing particular pillars. The only exception is environmental \& accident pillar.

To sum it up, the following Tab. 6 illustrates regions that have the most frequent representation of contributions in each pillar. Three regions with the highest number of contributions per capita have been always selected. 
Tab. 6: Regions with the most frequent representation of contributions in each pillar

\begin{tabular}{l|c} 
All pillars together & Central Bohemia \& Prague, Liberec, Karlovy Vary \\
\hline SOCIAL & Central Bohemia \& Prague, Karlovy Vary, Liberec \\
\hline ENVIRONMENTAL & Hradec Králové, Liberec, South Bohemia \\
\hline ECONOMIC & Central Bohemia \& Prague, Karlovy Vary, Ústí nad Labem \\
\hline PUBLIC AFFAIRS & Karlovary Vary, Central Bohemia \& Prague, Hradec Králové \\
\hline EDUCATION \& SCIENCE & PIzeň, Liberec, Central Bohemia \& Prague \\
\hline EUROPEAN \& INTERNATIONAL & Central Bohemia \& Prague, Olomouc, South Bohemia \\
\hline SECURITY & Central Bohemia \& Prague, Karlovy Vary, PIzeň \\
\hline ACCIDENTS & Liberec, Karlovy Vary, Plzeň \\
\hline JUSTICE & Hradec Králové, Central Bohemia \& Prague, PIzeň \\
\hline SPORT & Liberec, Pardubice, Central Bohemia \& Prague \\
\hline
\end{tabular}

Source: authors

The bolded regions in Tab. 6 are found in top three regions in relation to a separate pillar, but not in the full profile. The most frequent bolded are Plzeň and Hradec Králové regions. If we look in more detail at Tab. 6 we can notice some interesting exceptions. For instance, South Bohemia region significantly occur in environmental and European \& international pillars (atomic power plant and disputes with neighbouring Austria), Ústí nad Labem region in economic pillar (problems with the restructuring of heavy industry), Olomouc region in European \& international pillar (historical city with the seat of the Archdiocese of Moravia) and Pardubice region in sport pillar (famous ice hockey club with a new stadium, Velká pardubická steeplechase).

\section{c) Hypothesis H3: Independence between region and pillar variables can be expected.}

To evaluate hypothesis $H 3$ the methods of correspondence analysis will be used. In that case we will work with absolute number of contributions, so that we will not take into account the size of the regions (per capita) or other transformation of data as we did in our previous analysis.

First of all we have to test the independence between region and pillar variables, see Tab. 7 .

\section{Tab. 7: Measures of dependence in contingency table}

\begin{tabular}{l|c|c} 
& Value & Asymptotic Significance \\
\hline Pearson Chi-Square & $3,602.409$ & 0.000 \\
\hline Cramer's $V$ & 0.086 & \\
\hline$N$ of valid cases & 54,667 & \\
\hline
\end{tabular}

Source: authors

The significance of chi-square test is less than 0.05 , so that the dependence between regions and pillars can be proved. In order to present described dependence among thematic pillars and regions graphically the correspondence analysis consisting of 2 dimensions was used. The results of correspondence analysis are presented as a scatter biplot, see Fig. 6. For completeness of our analysis we should add that the correspondence analysis describes $69.3 \%$ of relationships in the contingency table which is higher value than on average. 
Fig. 6: Scatter biplot for both pillars and regions (NUTS III)

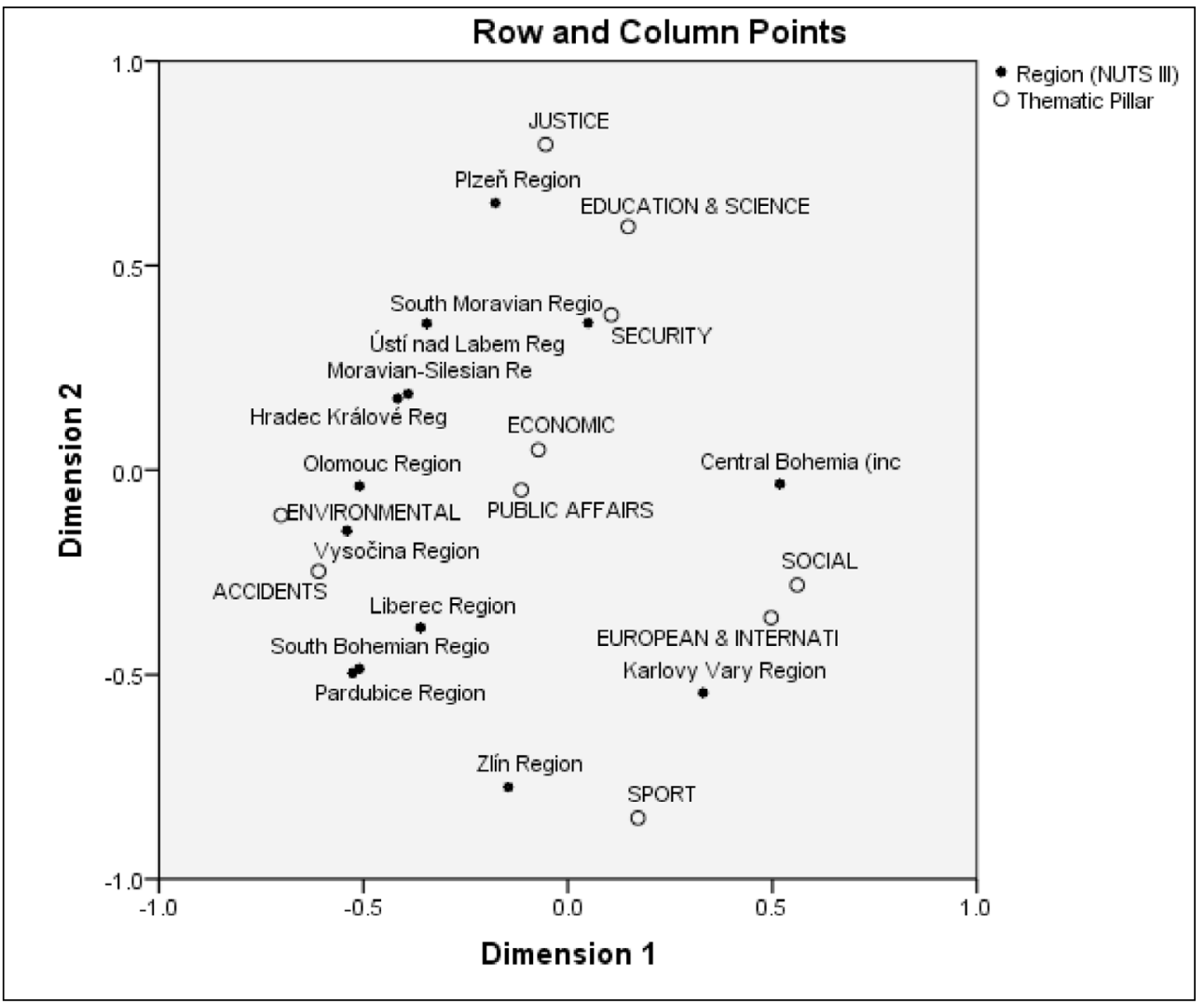

Source: authors

When analysing Fig. 6 one can see some clear relations among regions and pillars. Plzeň region is very tightly linked with education \& science and justice pillars thanks to the affair of the Faculty of Law. Karlovy Vary region is closely related to European \& international and social pillars due to the annually held International Film Festival, famous spa as well as large and economically powerful Russianspeaking minority. Fig. 6 also confirms specificity of Central Bohemia \& Prague region which does not neighbour with any other region or pillar. Central Bohemia \& Prague region is the capital city region so that it is untypical in the number of contributions per capita and thematic structure. This region is located in the middle right part of Fig. 6 that means the greater amount of "long term issues" topics. On the other hand Zlín region shows a very small number of contributions per capita in most pillars, making it uninteresting region for journalists. Zlín region is situated in the middle bottom of Fig. 6 and can be partly linked with sport just due to the presence of many sport clubs mainly in regional metropolis.

The next interesting information that can be derived from the Fig. 6 is the relative proximity of Moravian-Silesian and Ústí NUTS III regions. In both cases we are dealing with traditional industrial regions that were compelled to undergo rather painful transformation in recent years and their socioeconomic characteristics bear a great resemblance.

Proximity of certain regions and pillars appears to be seemingly surprising; nearness of Vysočina region and accidents pillar can be 
attributed to the presence of principal highway in the country as well as to an army helicopter accident in 2004 and another army aircraft crash in 2010. The region itself is less populous and moreover partly of rural character. In case of South Moravian region and security pillar, the explanation consists in serious affair of children abuse within religious sect in 2007 and bribery at the Brno city hall in 2010. However, we should confess certain proximities like Moravian-Silesian and Hradec Králové regions or South Bohemian and Pardubice regions can be barely explained if we disregard gatekeeping principles.

\section{Conclusions}

This paper confirms the importance of TV contributions, which appear in national broadcasting and are related to individual regions within the country. Division of themes into 10 pillars turned out to be very useful just for the sake of further conceptualization of regional media portrayals.

Correspondence analysis confirmed that structure of contributions of both private TV stations bears a certain resemblance, which is palpable mainly in the concentration on commercial or tabloid issues. Coverage of private TV Nova and FTV Prima differs significantly from that of public Czech TV, which indeed deals with public affairs more intensely. It should be also added public Czech TV produces two different news programs with relatively distinct profiles.

For the purposes of further analysis, unification of Prague with surrounding Central Bohemia proved to be useful. This newly created territorial unit is in compliance with natural geographical characteristics on the one hand and eliminates the specific urban character of Prague - so dissimilar with other NUTS III regions - on the other. In that way, the comparison of individual regions has been facilitated.

Analysis of variance represented by nonparametric Kruskal-Wallis test was used for the verification of hypotheses $H 1$ and $H 2$. Hypothesis $H 1$ "The average number of contributions in each thematic pillar is comparable within individual regions" was rejected at $5 \%$ significance level. The same, i.e. the rejection at $5 \%$ significance level applies also to hypothesis $H 2$ formulated as follows: "The representation of contributions from a particular pillar is comparable among regions".

Hypothesis $H 3$ was evaluated via application of chi-square test and correspondence analysis. The hypothesis, which sounds "Independence between region and pillar variables can be expected", was rejected too. For instance, Plzeň region can be associated with education \& science or justice pillars, Vysočina with accidents pillar or South Moravian region with security pillar.

To sum it up, our paper revealed that media landscape of the Czech Republic does not always comply with genuine features of individual regions. Editorial stereotypes manifest themselves rather strongly and we are indeed entitled to talk about importance of gatekeeping. And since an amazingly small amount of research has been done on the relation between media and regions, both scholars and practitioners face an indubitable challenge in their future activities.

The support provided by VSB-TU Ostrava under the SGS project SP2014/103 and by Operational Programme Education for Competitiveness, Project No. CZ.1.07/2.3.00/20.0296 is kindly announced.

\section{References}

[1] AMIN, A. and THRIFT, N. Institutional issues for the European regions: from markets and plans to socioeconomics and powers of association. Economy and Society. 1995, Vol. 24, Iss. 41, pp. 41-66. ISSN 0308-5147.

[2] DE FLEUR, M.L. and DE FLEUR, M. Mass Communication Theories: Explaining Origins, Processes, and Effects. London: Pearson, 2009. ISBN 0-205-33172-6.

[3] FAGERLAND, M.W. and SANDVIK, L. The Wilcoxon-Mann-Whitney test under scrutiny. Statistics in Medicine. 2009, Vol. 28, Iss. 10, pp. 1487-1497. ISSN 1097-0258.

[4] FRANKLIN, B. and MURPHY, D. Making the Local News: Local Journalism in the Context. London, Routledge, 1991. ISBN 978-04-151-6803-8.

[5] GOULD, P. and WHITE, R. Mental maps. London: Routledge, 1986. ISBN 0-41-508482-2.

[6] GREENACRE, M. Theory and Applications of Correspondence Analysis. 1st ed. London: Academic Press, 1983. ISBN 0-12-299050-1.

[7] HIRSCHFELD, H.O. A connection between correlation and contingency. Proc. Cambridge 
Philosophical Society. 1935, Vol. 31, pp. 520-552. ISSN 0305-0041.

[8] KARLSSON, C. and PICARD, R., et al. Media Clusters. Spatial Agglomeration and Content Capabilities. Cheltenham: Edward Elgar, 2011. ISBN 978-0-85793-268-6.

[9] KOTLER, P., HAIDER, D.H. and REIN, I. Marketing Places: Attracting Investment, Industry and Tourism to Cities, States and Nations. 1st ed. New York: Free Press, 1993. ISBN 0-0291-7596-8. [10] LLOYD, R. Cognition, preference and behavior in space. Economic Geography. 1976, Vol. 52, Iss. 3, pp. 241-253. ISSN 1944-8287.

[11] MCCOMBS, M.E. and SHAW, D.L. The Agenda-Setting Functions of the Mass Media. Public Opinion Quarterly. 1972, Vol. 36, Iss. 2, pp. 176-187. ISSN 0033-362X.

[12] MCQUAIL, D. Úvod do teorie masové komunikace. Praha: Portál, 2009. ISBN 978-807367-574-5.

[13] MELOUN, M. and MILITKÝ, J. Kompendium statistického zpracování dat. 2nd ed. Praha: Academia, 2006. ISBN 80-200-1396-2.

[14] NEČAS, V. Mediální kontext české zahraniční politiky. In: KOŘAN, M., et al. Česká zahraniční politika $v$ roce 2007. Praha: Ústav mezinárodních vztahů, 2008. pp. 41-48. ISBN 978-80-86506-67-8. [15] SHOEMAKER, P., EICHHOLZ, M., KIM, E. and WRIGLEY, B. Individual and routine forces in gatekeeping. Journalism \& Mass Communication Quarterly. 2001, Vol. 78, Iss. 2, pp. 233-246. ISSN 1077-6990.

[16] SUCHÁČEK, J. and SEĎA, P. Territorial Marketing in the Czech Republic: Between PathDependency and Learning. In: Liberec Economic Forum 2011. Liberec: Technical University of Liberec, 2011, pp. 439-447. ISBN 978-80-7372-755-0.

[17] SUCHÁČEK, J., SED̆A, P. and FRIEDRICH, $V$. Media as an external factor influencing marketing milieu of Czech towns: A quantitative perspective. In: Liberec Economic Forum 2013. Liberec: Technical University of Liberec, 2013. pp. 532-541. ISBN 978-80-7372-953-0.

[18] SUCHÁČEK, J., SEĎA, P. and FRIEDRICH, $\mathrm{V}$. Regions and media from quantitative and quali- tative perspectives: the case of Czech Republic. Acta Universitatis Agriculturae et Silviculturae Mendelianae Brunensis. 2013, Vol. 61, Iss. 7, pp. 329-336. ISSN 1211-8516.

[19] STEFKO, R., HABANIK, J. and SINDLERYOVA, I. Marketing Instrumentary in the Process of Project Acceptation within the Acceleration of Back-warded Regions Development. Ekonomický časopis. 2010, Vol. 58, Iss. 5, pp. 512-526. ISSN 0013-3035.

[20] WHITE, H. Where do markets come from? American Journal of Sociology. 1981, Vol. 87, Iss. 3, pp. 514-547. ISSN 0002-9602.

doc. Ing. Jan Sucháček, Ph.D. Technical University of Ostrava Faculty of Economics Department of Regional and Environmental Economics jan.suchacek@vsb.cz

Ing. Václav Friedrich, Ph.D. Technical University of Ostrava Faculty of Economics Department of Mathematical Methods in Economics vaclav.friedrich@vsb.cz

Ing. Petr Seda, Ph.D.

Technical University of Ostrava Faculty of Economics Department of Mathematical Methods in Economics petr.seda@vsb.cz

RNDr. Jaroslav Koutský, Ph.D. Jan Evangelista Purkyně University in Ústí nad Labem

Faculty of Social and Economic Studies Department of Regional and Local Development jaroslav.koutsky@ujep.cz 


\title{
Abstract
}

\section{MEDIA PORTRAYALS OF REGIONS IN THE CZECH REPUBLIC: SELECTED ISSUES}

\author{
Jan Sucháček, Petr Sed’a, Václav Friedrich, Jaroslav Koutský
}

Amount of information provided by media is growing virtually every day. Surprisingly, attention devoted to the spatial implications of media information is far from sufficient. Existing researches bring ample evidence that TV coverage embodies media agenda in a satisfactory manner as it has rather profound impact on the public on the one hand and is representative enough on the other. Our paper deals with TV news reporting related to NUTS III regions in the Czech Republic. The main perspective adopted in this article is a qualitative one, which facilitates the evaluation of TV news contents. We are deliberately focusing on national TV broadcasting, which is the most influential one. Individual contributions we evaluate appeared in the framework of news reporting in public Czech TV and private Nova and Prima. In spite of severe limitations in media data, our paper covers the period between the years 2004 and 2011, which helps to underpin our conclusions in a sufficient way. Contributions, which are related to individual NUTS III regions and resonate at the national level, constitute the focal point of our research. TV reflection of material reality is of intangible character; nonetheless similarly to material categories, one can identify spatial as well as thematic differentiation and even patterns also in the sphere of TV news reporting. There are only little doubts that media landscape and closely associated mental maps have been largely underestimated so far. Thus, these topics represent one of pivotal theoretical and practical challenges in the field of spatial sciences, which holds true for post-transition country even more.

Key Words: NUTS III regions, Czech Republic, media, TV news reporting, analysis of variance, correspondence analysis.

JEL Classification: B52, R10, R19, M30, M39, Z10.

DOI: 10.15240/tul/001/2014-4-010 